DOI https://doi.org/10.30525/978-9934-26-004-9-2

\title{
ПРИЗНАЧЕННЯ ІНТЕРПРЕТАТИВНОЇ АНТРОПОЛОГІЇ
}

\author{
Брагіна Т. М. \\ кандидат філософських наук, \\ дочент кафедри культурології \\ Александрова М. В. \\ кандидат філософських наук, \\ дочент кафедри культурологіі \\ Харківської державної академії культури \\ Брагін Ю. А. \\ кандидат культурології, \\ старший викладач кафедри культури \\ Харківського начіонального технічного університету \\ сільського господарства імені Петра Василенка \\ м. Харків, Украӥна
}

Актуальність теми розвідки зумовлена необхідністю вдосконалення методології культурологічного пізнання Семіотична концепція науки про культуру К. Гірца орієнтована на інтерпретацію і пошук значень «ззовні загадкових виразів соціального». Автор ставить задачу утворення «внутрішньо узгодженої» концепції культури, яка була б у теоретичному плані більш спроможною, ніж тайлорівське визначення культури як «складного цілого», або багатостороннього визначення культури К. Клакхона [1, с. 10, 11].

К. Гірц відхиляє підхід, який стверджує, що «культуру складають психічні структури, за допомогою яких індивіди або групи індивідів формують свою поведінку». Він уважає когнітивістською помилкою потрактування, яке розглядає культуру як сукупність ментальних феноменів. На його думку, культура $є$ «публічною, тому що комунікація і значення $є$ публічними» [1, с. 18-20]. К. Гірц розглядає не психологічний процес мислення, а його «продукт» [2, с. 3]. Автор протиставляє «уніфікаційний» погляд на мислення як внутрішній психологічний процес «плюралістичному» погляду на думку як соціальний факт. За його твердженням, невідповідність цих підходів спочатку була подана як проблема «примітивного мислення», потім як проблема «когнітивного релятивізму», i, кінець кінцем, як проблема «концептуальної несумірності» $[2$, с. 3,4$]$. 
К. Гірц уважає, що оскільки мислення, таким, яким воно $є$ у «природі», завжди різноманітне, то дослідники запропонували «зняти питання 3 підгрунтя павутиноподібного світу ментальності і поставити його знов на нібито більш міцному підгрунті світу значень». Тепер те, що раніше уявлялося справою порівняння психологічних процесів у різних народів, стало розглядатися як «питання сумірності концептуальних структур однієї дискурсивної спільноти з іншою» [2, с. 5, 6].

Така зміна формулювання веде до того, що К. Гірц називає «практичною епістемологією». Той факт, що думка $\epsilon$ різноманітною як продукт і одноманітною як процес, стає не просто парадоксом соціальних наук, котрий є рушієм дослідницьких пошуків, але і сама природа цього парадоксу починає пов'язуватись 3 «проблемою перекладу, 3 тим, як поняття з однієї системи значень можуть бути виражені у іншій системі, тобто $з$ культурною герменевтикою, а не 3 концептуальною механікою». На його думку, у такій постановці проблема «встає на свою колію», оскільки питання виникнення розуміння між прибічниками тих наукових концепцій, що сперечаються, тепер стає «рівним питанню про те, як християнин може зрозуміти мусульманина, європеєць - азіата, а антрополог - місцевого мешканця». Те, що раніше виглядало як задача 3'ясування того, чи можуть примітивні люди відрізнити факт від фантазії, тепер виглядає задачею з'ясування того, у який спосіб інакші люди організують свій значущий світ.

У фокусі уваги тепер опиняється «існуюче різноманіття сучасної думки саме по собі» [2, с. 6]. «Етнографія мислення», до створення якої закликає автор, являє «собою захід історичний, соціологічний, порівняльний, інтерпретативний..., у який залучаються усі доступні інструменти; захід, ціль якого - зробити неясні матерії зрозумілими шляхом улаштування їх в інформативний контекст». 3 цієї точки зору здатність до формування ідей $\epsilon$ «культурним артефактом». Культура розглядається як «феномен, який можна характеризувати, розглядаючи його зовнішні вирази з точки зору діяльності, яка створює ці зовнішні вирази» [2, с. 7].

Оскільки «мислення починає розглядатися як таке, що плине у річищі символічних форм, присутніх у тій чи іншій спільноті (мова, мистецтво, міф, теорія, ритуал, технологія, право), то аналіз таких форм і таких спільнот стає складовою інтерпретації, а не іiі допоміжним механізмом». Тому соціологія знання має розглядати пізнавальні здібності «безпосередньо як соціальні явища самі по собі». Такий аналіз «використання символів 3 точки зору соціальної дії» має вести до утворення «зовнішньої» психології [2, с. 7].

Автор у такий спосіб пояснює метод, застосовуваний представниками інтерпретативної антропології: «Такі теоретики... використовують, по 
суті, семіотичний підхід до емоцій, - такий, який розглядає їх у термінах сигніфікативних інструментів і конструктивних практик, за допомогою котрих вони наділяються формою, змістом і вводяться до публічного обігу. Слова, образи, жести,... історії, обряди... $є$ не простими передавальниками почуттів, які мешкають у іншому місці, множиною рефлексій, симптомів... Вони правлять за місцеперебування і облаштунки самих речей» $[4$, р. 208]. Етнографія мислення має зосередитися на тому, як значенню вдається переходити у незмінній формі з одного дискурсу в інший, проблемі інтерсуб'єктивності, на тому, як змінюються «системи думки» і підтримуються норми мислення і ті [3, с. 123].

Одним 3 важливих «методологічних припущень» етнографії мислення $\epsilon$ те, що гуманітарні і природничо-наукові дисціплини $\epsilon$ «не просто інтелектуальними кутами зору», а «способами буття у світі». Тому розуміння образів Йєйтса або роздуму про чорні діри означає не просто «певне технічне завдання», а підхід до «цілої культурної сфери, яка визначає суттєву частину людського життя» [2, с. 9]. Інтерпретація має схопити стосунки між експресивними формами і почуттями, котрі самі пов'язані з культурою і отримують свою значущість від того місця, яке вони посідають у життєвому досвіді певного суспільства. На думку К. Гірца, дослідження розглядає «значення емоції $\mathrm{i}$, якомога це можливо, картографує концептуальний простір його розповсюдження» $[4$, p. 208, 209]. Етнографія сучасної думки вбачається йому «проектом імперативного характеру» - адже ролі, котрі, як нам здається, ми просто тимчасово приймаємо, перетворюються на свідомості, котрі «ми носимо у наших головах». «Сутність речей» наукової сфери демонструє себе, зокрема, у тому, що академічні спільноти небагато у чому відрізняться від «звичайних селянських поселень» $[2$, с. 9, 10].

Тут автор втрачає предмет розгляду, тобто специфіку наукової предметності. Застосування етнографічних понять до фактів наукової дійсності він видає за «сутність речей». Але застосовані у подібний спосіб поняття біології привели би до висновку про те, що «сутність речей» науки полягає у тому, що вчені $є$ тваринами. Логічна природа наукової предметності підміняється складеною на іiі підгрунті конструкцією фактів, якій надається реальність, речова наявність. Але такий погляд розмиває науковий підхід, який формується на межі поділу реального підгрунтя і підстави пізнання.

Автор указує на особливі реальності, які належать предмету етнографії знання - когнітивні процеси як «соціальні явища самі по собі». Однак ці реальності, у його потрактуванні, є проявами свідомості індивіда, а не наукового мислення дослідника. К. Гірц розмірковує не про наукове мислення суб'єкта пізнання, яке конституюється на матеріалі предмета даної науки i тому має наукову специфічність, а про свідомість 14 
представника «наукового етносу». Відтак, тут впроваджується точка зору, у відповідності до якої наука розглядається як продовження природної установки «цілісного індивіда», залученого до наукової діяльності.

Особливості ментального механізму, задіяного у теоретичному дослідженні, редукуються до «практичного розуму» індивіда, дії якого визначаються об'єктивними соціальними значеннями. Але оскільки ці значення $є$ соціальними, остільки ця когнітивна схема виключає проблему формування інтерсуб'єктивності. Оскільки К. Гірц розглядає не наукову специфіку мислення дослідника, а соціальну специфіку свідомості представника «інтелектуального села», то когнітивний аспект розгляду замінюється аспектом соціального буття.

Отже, специфічна конкретика послідовності пізнавальних операцій суб'єкта, націлених на особливий культурний феномен, підміняється фіксацією сукупності об’єктивних соціальних значень, у середовищі яких розгортається його існування. Але виставлена за двері суб'єктивність повертається через вікно, як тільки постає питання про когнітивні засновки цієї операції. Залишається неясним, хто окрім суб'єкта пізнання може визначити критерій відбору релевантних для характеристики даного «інтелектуального села» значень.

Оскільки автор формує дискурс на підгрунті даних множини наук, які здатні надати інформативності культурному феномену, то залишається неясним, хто визначає межі цієї множини. I, нарешті, дані тільки «здатні надати інформативності» дискурсу, але утворюється вона дослідником, котрий застосовує епістемологічно грунтовні концептуальні схеми. Відтак, сутність питання полягає у демонстрації когнітивної обгрунтованості цієї процедури.

\section{Література:}

1. Гирц К. Интерпретация культур. М.: РОССПЭН, 2004. 560 с.

2. Гирц К. Как мы сегодня думаем. Этногр. обозрение. 2007. № 2. C. $3-16$.

3. Джулай Ю. В. Кліфорд Гірц: герменевтичний підхід до теорії в культурній антропології. Магістеріум. К.: Нац. ун-т «Києво-Могилян. акад.», 2001. Вип. 19 : Культурологія. С. 123-128.

4. Geertz C. Available Light: Anthropological Reflections on Philosophical Topics. Princeton: Princeton University Press, 2000. 271 p. 